JIME (Journal of Industrial and Manufacture Engineering)

Available online http://ojs.uma.ac.id/index.php/jimeＥmail: jime@uma.ac.id

\title{
Analisis Perhitungan dan Penentuan Harga Pokok Produksi pada PT. Mutifa Medan
}

\section{Analysis Of Calculation And Determination of Cost Of Production At PT Mutifa Medan}

\author{
John Fisher Gulo*1) Kamil Mustafa2) \& Ninny Siregar ${ }^{3)}$ \\ Program Studi Teknik Industri, Fakultas Teknik, Universitas Medan Area, Indonesia \\ Diterima: April 2019; Disetujui: April 2019; Dipublikasi: April 2019; \\ * Corresponding author: johnfishergulo@gmail.com
}

\begin{abstract}
Abstrak
Biaya produksi sangat diperlukan untuk menentukan harga pokok produksi suatu produk. Biaya yang dikeluarkan untuk menghasilkan produk harus jelas, sehingga penentuan harga pokok produksinya akan tepat. Ketidaktepatan dalam perhitungan harga pokok produksi akan menyesatkan manajemen dalam membuat keputusan. Metode pengumpulan data yang digunakan dalam penelitian ini antara lain : Dokumentasi, Wawancara, Observasi. Penelitian ini dianalisis dengan menggunakan analisis deskriptif kualitatif yaitu membandingkan antara teori dengan hasil senyatanya yang ada di perusahaan. PT MUTIFA dalam menentukan harga pokok produksi menggunakan metode full costing. PT MUTIFA dalam menentukan harga pokok produksi, semua biaya yang dikeluarkan diperlakukan sebagai biaya produksi, baik biaya bahan baku utama, biaya bahan penolong, biaya bahan kemasan maupun overhead produksi. penggolongan biaya produksinya telah sesuai dengan teori yang ada yaitu terdiri dari biaya produksi, biaya tenaga dan biaya overhead produksi. Total biaya produksi perbulan dari setiap perhitungan elemen biaya rata-rata perbulan adalah Rp. 73.111.118,260,- dan jumlah rata-tata produk jadi Parasetamol tablet 500mg adalah sebanyak 566.666,67 tablet setiap bulannya. Berdasarkan perhitungan data rata-rata biaya produksi pada tahun 2009, maka Harga pokok produksi per tablet adalah Rp 129.019,-

Kata Kunci : analisis perhitungan, penentuan harga.
\end{abstract}

\begin{abstract}
The cost of production is needed to determine the cost of production of a product. Costs incurred to produce the product must be clear, so that the determination of the cost of production would be appropriate. Imprecision in calculating the cost of production will be misleading in making management decisions. Data collection methods used in this study include: Documentation, Interview, Observation. This study analyzed using qualitative descriptive analysis comparing the theory with actual results of the company. PT MUTIFA in determining the cost of production using the full costing method. PT MUTIFA in determining the cost of production, all costs incurred are treated as production costs, both the cost of major raw materials, cost of auxiliary materials, packaging materials costs and production overhead. Classification of production costs in accordance with the theory that exists is composed of material costs, labor costs and production overhead costs. Total production cost per month of each element calculation the average monthly cost is Rp. 73.111.118,260,- and the average number of finished products Paracetamol tablet $500 \mathrm{mg}$ tablet is as much $566,666.67$ per month. Based on data on average production costs in 2009, then the production cost per tablet is .Rp. $129,019$.
\end{abstract}

Keywords : calculation analysis, price fixing.

How to Cite: Gulo, Jhon Fisher, Mustafa, K \& Siregar, Ninny (2018), Analisis Perhitungan Dan Penentuan Harga Pokok Produksi Pada PT. Mutifa Medan, JIME (Journal of Industrial and Manufacture Engineering), 2(1): 12-17 


\section{PENDAHULUAN}

Perhitungan dan penentuan harga pokok produksi merupakan salah satu faktor yang sangat penting bagi perusahaan, sebab harga pokok produksi tersebut dapat digunakan sebagai acuan untuk menentukan harga jual produk, memantau realisasi biaya, menghitung laba atau rugi periodik, menentukan harga pokok persediaan, produk jadi dan produk dalam proses yang disajikan dalam neraca.

Perhitungan harga pokok produksi harus dilakukan dengan teliti, karena informasi biaya yang disajikan didalamnya dibutuhkan manajemen sebagai dasar pengambilan keputusan dan penetapan kebijakan perusahaan. Kebijakan penting yang berhubungan dengan informasi biaya ini adalah penentuan harga jual produk, penentuan laba dan penilaian persediaan produk jadi dan produk proses. Apabila terjadi kesalahan dalam penentuan hatga pokok produksi maka mengakibatkan pengambilan keputusan salah yang akan merugikan perusahaan. Kesalahan yang dimaksud adalah memasukkan unsur biaya yang seharusnya tidak ada dalam perhitungan harga pokok produksi dan kesalahan dalam membebankan kepada produk. Untuk menghindari kesalahan tersebut, yang perlu diperhatikan adalah ketelitian pembebanan biaya kepada produk.

Mengingat betapa pentingnya penentuan harga produk produksi bagi suatu perusahaan, maka penulis tertarik untuk mengadakan penelitian mengenai masalah perhitungan dan penentuan harga pokok produksi.

\section{METODE PENELITIAN}

Adapun yang menjadi bahan baku utama pembuatan Parasetamol Tablet $500 \mathrm{mg}$ di PT. MUTIFA, yakni Parasetamol atau dengan nama lain disebut Asetamin yang mengandung tidak kurang dan 99,0\% dan tidak lebih dan 101,0\% $\mathrm{C}_{8} \mathrm{H}_{9} \mathrm{NO}_{2}$ dihitung terhadap zat yang telah dikeringkan, berbentuk serbuk berwarna putih.

\section{Bahan Penolong}

Yang digunakan dalam proses produksi Parasetamol Tablet 500 mg terdiri dari:

- Amylum

- Magnesium Stearat

- Nipagin

- Saccharum Lactus

- Talkum

\section{Bahan kemasan}

bahan yang dibutuhkan untuk menyelesaikan suatu produk atau suatu bahan yang dikaitkan pada produk, dimana keberadaannya tidak mengurangi nilai dan produk tersebut.

- Aluminium Foil

- Brosur

- Isolatif

- Master Box dan Small box 


\section{Uraian Produksi}

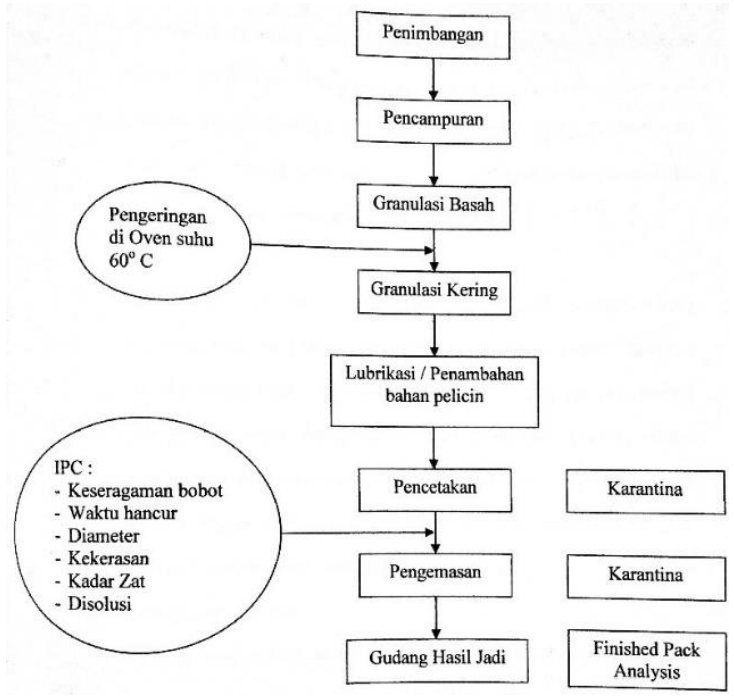

Gambar 1 Bagan Uraian Proses Produksi Paracetamol tablet 500mg

\section{HASIL DAN PEMBAHASAN}

\section{Harga Pokok}

Harga Pokok Produksi adalah semua pengeluaran yang dilakukan perusahaan untuk memproduksi suatu produk.

Tujuan dan Manfaat Penentuan Harga Pokok Produksi

- Sebagai dasar dalam penetapan harga jual

- Sebagai alat untuk menilai efisiensi proses produksi

- Sebagai alat untuk memantau realisasi biaya produksi

- Untuk menentukan laba atau rugi periodik

- Menilai dan menentukan harga pokok persediaan

Metode pengumpulan harga pokok ada dua yaitu metode harga pokok pesanan dan metode harga pokok proses. Kedua metode ini bertujuan untuk menentukan harga pokok produk, tapi dalam hal pembebanan kedua metode ini mempunyai penekanan dan fokus yang berbeda.

\section{Penggolongan Biaya}

Biaya merupakan suatu pengorbanan sumber daya ekonomi untuk mencapai tujuan tertentu yang bermanfaat pada saat ini atau masa yang akan datang. Penggolongan biaya ditentukan atas dasar tujuan yang hendak dicapai dengam penggolongan tersebut.

Menurut fungsi pokok perusahaan digolongkan menjadi biaya produksi, biaya pemasaran dan biaya administrasi umum.

Dalam hubungan dengan sesuatu yang dibiayai, dapat dikelompokkan menjadi biaya langsung dan biaya tidak langsung.

Menurut perilaku dalam hubungannya dengan perubahan volume kegiatan digolongkan biaya varibel, biaya semi variabel dan biaya tetap.

Sedangkan penggolongan biaya atas dasar jangka waktu manfaatnya yaitu pengeluaran modal dan pengeluaran pendapatan.

Elemen biaya pada penentuan harga pokok produksi yaitu : Biaya bahan baku, Biaya produksi tidak langsung dan biaya tenaga kerja.

\section{Metode Penentuan Harga Pokok Produksi}

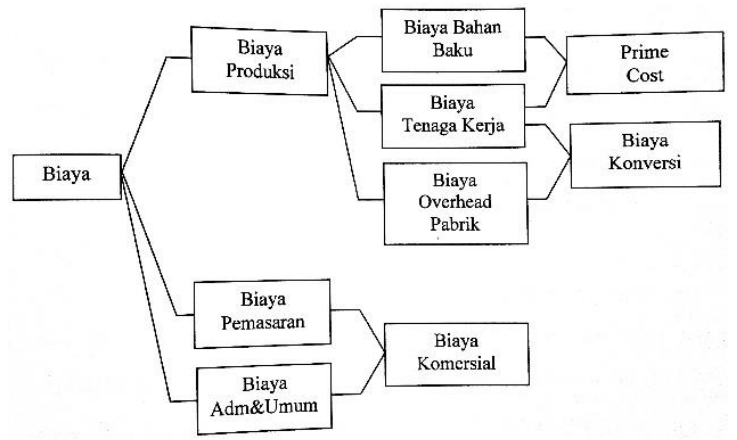

Gambar 2 Bagan Perincian Biaya 
Analisa Break Event Point

Suatu cara oenentuan hubungan antara biaya tetap, biaya variabel, volume kegiatan dan keuntungan. Juga merupakan suatu analisis untu kmenentukan dan mencari jumlah barang atau jasa yang harus dijual kepada konsumen pada harga tertentu untuk menutupi biaya yang timbul serta mendapatkan keuntungan/ profit.

Persamaan aljabar dalam perhitungan break event point :

- Perhitungan break event point atas dasar penjualan sales dalam rupiah,yang dapat dihitung dengan

$$
B E P=\frac{F C}{1-\frac{V C}{R}}
$$

- Perhitungan break event point atas dasar unit dapat dihitung dengan

$$
\mathrm{BEP}=\frac{F C}{P-\text { Harga pokok per tablet }}
$$

\section{Siklus Akuntansi Biaya}

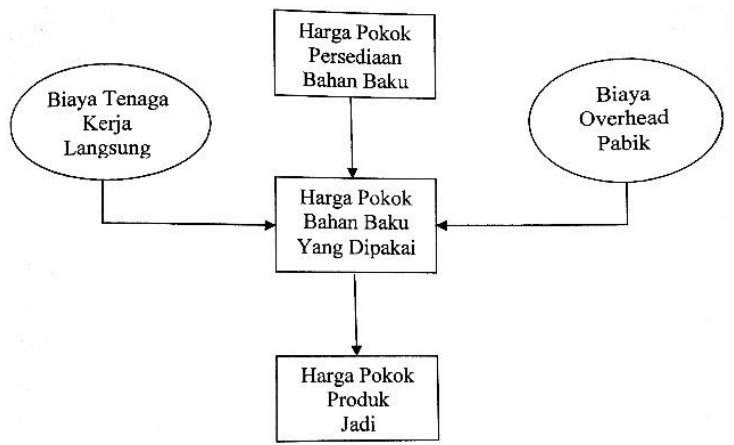

Gambar 3 Bagan Siklus Akuntansi Biaya

Tabel 1 Biaya rata-rata produksi

\begin{tabular}{|c|c|c|}
\hline NO & URAIAN & JUMLAH \\
\hline I & BIAYA LANGSUNG & \\
\hline \multirow[t]{3}{*}{1} & Bahan Baku Utama & \\
\hline & \multirow{2}{*}{ Parasetamol } & $44.794 .303,680$ \\
\hline & & - \\
\hline \multirow[t]{6}{*}{2} & Bahan Baku Penolong & \\
\hline & Amylum & $\underline{94.815 .690,000}$ \\
\hline & Magnesium Stearat & $126.107,135$ \\
\hline & Nipagin & $411.451,353$ \\
\hline & Saccharum Lactus & $546.065,330$ \\
\hline & Talcum & $23.728,235$ \\
\hline \multirow[t]{6}{*}{3} & Bahan Kemasan & \\
\hline & Aluminium Foil & $5.145 .327,980$ \\
\hline & Brosur & $55.692,000$ \\
\hline & Isolatif & $39.000,000$ \\
\hline & Master Box & $2.066 .479,200$ \\
\hline & Small Box & $1.020 .000,000$ \\
\hline 4 & Biaya Upah Langsung & $8.568 .000,000$ \\
\hline 5 & Biaya Penggunaan Air & $519.714,667$ \\
\hline 6 & Biaya Penggunaan Listrik & $1.169 .358,000$ \\
\hline 7 & Biaya Penggunaan Gas & $909.500,330$ \\
\hline II & BIAYA TIDAK LANGSUNG & \\
\hline 1 & $\begin{array}{l}\text { Biaya Pemeliharaan } \\
\text { Bangunan dan } \\
\text { Perlengkapan Gudang } \\
\end{array}$ & $610.191,167$ \\
\hline 2 & $\begin{array}{l}\text { Biaya Pemeliharaan } \\
\text { Bangunan dan } \\
\text { Perlengkapan Lab }\end{array}$ & $375.988,167$ \\
\hline 3 & $\begin{array}{l}\text { Biaya Pemeliharaan Mesin } \\
\text { dan Alat-alat Listrik }\end{array}$ & $957.870,833$ \\
\hline 4 & $\begin{array}{l}\text { Biaya Pemeliharaan } \\
\text { Ruangan dan Perlengkapan } \\
\text { Produksi }\end{array}$ & $631.951,830$ \\
\hline 5 & $\begin{array}{l}\text { Biaya Penyusutan Bagian } \\
\text { Produksi }\end{array}$ & $193.431,083$ \\
\hline 6 & $\begin{array}{l}\text { Biaya Sample dan } \\
\text { Pendaftaran }\end{array}$ & $240.000,000$ \\
\hline 7 & Biaya Asuransi & $972.959,000$ \\
\hline 8 & Biaya Transportasi & $2.640 .995,000$ \\
\hline 9 & Biaya luran Farmasi & $165.000,000$ \\
\hline 10 & Biaya Kesejahteraan & $592.128,000$ \\
\hline III & $\begin{array}{l}\text { BIAYA ADMINISTRASI } \\
\text { PABRIK / PENGOLAHAN }\end{array}$ & \\
\hline 1 & $\begin{array}{l}\text { Biaya Penggunaan Alat } \\
\text { Tulis Kantor }\end{array}$ & $241.059,583$ \\
\hline IV & JUMLAH & 73.111.118,26 \\
\hline
\end{tabular}
Paracetamol tablet 500 mg 
John Fisher Gulo, Kamil Mustafa \& Ninny Siregar, Analisis Perhitungan Dan Penentuan Harga Pokok Produksi Pada PT. Mutifa Medan

\section{Perhitungan Break Event Point}

Tabel 2 Fixed Cost/ Biaya Tetap

\begin{tabular}{|c|c|c|}
\hline $\begin{array}{l}\text { Biaya Administrasi Pabrik } \\
\text { / Pengolahan Langsung }\end{array}$ & $\mathrm{Rp}$ & $241.059,580$ \\
\hline Biaya Asuransi & $\mathrm{Rp}$ & $972.959,000$ \\
\hline Biaya Iuran Farmasi & $\mathrm{Rp}$ & $165.000,000$ \\
\hline Biaya Kesejahteraan & $\mathrm{Rp}$ & $592.128,000$ \\
\hline Biaya / Upah Langsung & $\mathrm{Rp}$ & $8.568 .000,000$ \\
\hline $\begin{array}{l}\text { Biaya Penyusutan Bagian } \\
\text { Produksi }\end{array}$ & $\mathrm{Rp}$ & $193.431,080$ \\
\hline $\begin{array}{l}\text { Biaya Sampel dan } \\
\text { Pendaftaran }\end{array}$ & $\mathrm{Rp}$ & $240.000,000$ \\
\hline Biaya Transportasi & $\mathrm{Rp}$ & $2.640 .995,000$ \\
\hline Jumlah & \multicolumn{2}{|c|}{ Rp13.613.572,660 } \\
\hline
\end{tabular}

Tabel 3 Variable Cost/ Biaya Variabel

\begin{tabular}{|l|cr|}
\hline Biaya Penggunaan Air & $\mathrm{Rp}$ & $519.714,660$ \\
\hline Biaya Bahan Baku & $\mathrm{Rp}$ & $44.794 .303,680$ \\
\hline Biaya Bahan Penolong & $\mathrm{Rp}$ & $1.202 .167,740$ \\
\hline Biaya Penggunaan Gas & $\mathrm{Rp}$ & $909.500,330$ \\
\hline Biaya Bahan Kemasan & $\mathrm{Rp}$ & $8.326 .499,180$ \\
\hline Biaya Penggunaan Listrik & $\mathrm{Rp}$ & $1.169 .358,000$ \\
\hline $\begin{array}{l}\text { Biaya Pemeliharaan } \\
\text { Bangunan \& Perlengkapan } \\
\text { Gudang }\end{array}$ & $\mathrm{Rp}$ & $610.191,160$ \\
\hline $\begin{array}{l}\text { Biaya Pemeliharaan } \\
\text { Bangunan \& Perlengkapan } \\
\text { Lab }\end{array}$ & $\mathrm{Rp}$ & $375.988,160$ \\
\hline $\begin{array}{l}\text { Biaya Pemeliharaan } \\
\text { Ruangan \& Perlengkapan } \\
\text { Produksi }\end{array}$ & $\mathrm{Rp}$ & $631.951,830$ \\
\hline $\begin{array}{l}\text { Biaya Pemeliharaan Mesin } \\
\text { \& Alat-alat Listrik }\end{array}$ & $\mathrm{Rp}$ & $957.870,830$ \\
\hline Jumlah & $\mathrm{Rp}$ & $59.497 .545,670$ \\
\hline
\end{tabular}

Tabel 4 Volume Produk Jadi

\begin{tabular}{|c|c|c|}
\hline No & Bulan & $\begin{array}{c}\text { Jumlah Produksi } \\
\text { (tablet) }\end{array}$ \\
\hline 1 & Januari & 600.000 \\
\hline 2 & Februari & 600.000 \\
\hline 3 & Maret & 700.000 \\
\hline 4 & April & 500.000 \\
\hline 5 & Mei & 600.000 \\
\hline 6 & Juni & 600.000 \\
\hline 7 & Juli & 400.000 \\
\hline 8 & Agustus & 400.000 \\
\hline 9 & September & 600.000 \\
\hline 10 & Oktober & 700.000 \\
\hline 11 & November & 600.000 \\
\hline 12 & Desember & 500.000 \\
\hline \multicolumn{2}{|r|}{ Jumlah } & 6.800 .000 \\
\hline
\end{tabular}

Tabel 5 Persentasi Keuntungan

\begin{tabular}{|r|c|c|c|c|}
\hline $\begin{array}{c}\text { Persentase } \\
\text { Keuntungan }\end{array}$ & $\begin{array}{c}\text { Harga } \\
\text { Pokok } \\
\text { Produksi }\end{array}$ & Harga & $\begin{array}{c}\text { Jumlah } \\
\text { Produk }\end{array}$ & Keuntungan \\
\hline $10 \%$ & 129,019 & 141,92 & $566.666,67$ & $7.311 .076,70$ \\
\hline $20 \%$ & 129,019 & 154,822 & $566.666,67$ & $14.622 .153,41$ \\
\hline $30 \%$ & 129,019 & 167,724 & $566.666,67$ & $21.933 .230,12$ \\
\hline $40 \%$ & 129,019 & 180,626 & $566.666,67$ & $29.244 .306,83$ \\
\hline $50 \%$ & 129,019 & 193,528 & $566.666,67$ & $36.555 .383,54$ \\
\hline $60 \%$ & 129,019 & 206,43 & $566.666,67$ & $43.866 .460,25$ \\
\hline $70 \%$ & 129,019 & 219,332 & $566.666,67$ & $51.177 .536,96$ \\
\hline $80 \%$ & 129,019 & 232,234 & $566.666,67$ & $58.488 .613,67$ \\
\hline $90 \%$ & 129,019 & 245,136 & $566.666,67$ & $65.799 .690,38$ \\
\hline $100 \%$ & 129,019 & 258,038 & $566.666,67$ & $73.110 .767,09$ \\
\hline & & & &
\end{tabular}

\section{SIMPULAN}

Dan hasil penelitian dan analisis diatas dapat disimpulkan bahwa

- PT. MUTIFA menggunakan metode full costing di dalam penentuan harga pokok produksinya. Hal ini sesuai dengan teori, dimana harga pokok Produksi dihitung dengan menjumlahkan seluruh biaya produksi yang terjadi dalam periode tertentu. Biaya rata-rata produksi per bulan sebesar Rp. 73.111.118,260,- dengan jurnlah rata-rata produk jadi Parasetamol sebanyak 566.666,67 tablet setiap bulannya.

- PT. MUTIFA dalain menentukan harga pokok produksi, semua biaya yang dikeluarkan diperlakukan sebagai biaya produksi, baik biaya bahan baku utama, biaya bahan baku penolong, maupun biaya tidak langsung. Penggolongan biaya produksinya telah sesuai dengan teori yang ada yaitu terdiri dari biaya bahan, biaya tenaga kerja dan biaya overhead produksi. Sehingga harga pokok produksi per tabletnya adalah sebesar Rp. 129,019,- 


\section{DAFTAR PUSTAKA}

Adikoesoemah, Soemita. R. 1982. Biaya dan Harga Pokok. Bandung : Tarsito

Arikunto, Suharsimi. 2002. Prosedur Penelitian Suatu Pendekatan Prakek. Jakarta : Penerbit Rineka Cipta.

Baridwan, Zaki 1991. Sistem Akuntansi Penyusunan Prosedur dan Metode (Edisi Kelima). Yogyakarta: BPFE UGM.

Hadibroto, S. 1980. Masalah Akuntansi 1. Jakarta: Lembaga Penerbit FE UI.

Ikatan Akuntansi lndonesia. 1984. Prinsip Akuntansi Indonesia. Percetakan Negara Indonesia: Penerbit Rineka Cipta.
Manullang, M. 1980. Pengantar Ekonomi Perusahaan Medan: Penerbit Ghalia Indonesia

Mulyadi. 1986. Akuntansi Biaya: Penentuan Harga Pokok dan Pengendalian Biaya (Edisi ketiga). Yogyakarta: Penerbit FE UGM.

Riyanto, Bambang. 1980. Dasar dasar Pembelanjaan Perusahaan (edisi Kedua). Yogyakarta: Yayasan Penerbit Gadjah Mada

Sinuraya S. 1993. Akuntansi Perusahaan Industri. Medan: Penerbit CV Joehanda.

http//www.scribd.com/doc/19562067/Penent uan- Harga-Pokok-Produksi 